\title{
MORAL TRANSGRESSION AND ILLNESS IN THE EARLY MODERN NORTH ${ }^{1}$
}

\author{
Jari Eilola
}

University of Jyväskylä

\begin{abstract}
This article seeks to understand how people in the early modern age interpreted the nature of illness and the role that morality played in these interpretations. From this point of view illnesses were not only psycho-physical states or subjects for medical diagnosis but they were also subjects for narratives or stories through which people tried to understand what had caused their illness, and why it was happening to them. Illnesses were understood as strictly connected with the patient's character and were regarded as possible consequences of his personality. On the other hand, the interpretations also emphasised the ambivalence of a healer. Personal experiences and an understanding of one's life situation intertwined in these stories.
\end{abstract}

KEY WORDS: Morality. Folk healing. Diagnosis. Aetiological models. Ambivalence of a healer.

\section{TRANSGRESIÓN MORAL Y ENFERMEDAD EN LOS PAÍSES MÓRDICOS EN LA TEMPRANA EDAD MODERNA}

\section{RESUMEN}

Este artículo tiene por objetivo comprender la manera como las personas, en la temprana edad moderna, interpretaban la naturaleza de las enfermedades y qué papel desempeñaba la moralidad en estas interpretaciones. Desde este punto de vista, las enfermedades no eran solo estados psicofísicos u objeto de diagnósticos médicos sino que también eran objeto de relatos e historias a través de los cuales las personas intentaban comprender cuál era la causa de su enfermedad y por qué les pasaba a ellos. Se creía que las enfermedades estaban estrictamente relacionadas con el carácter de los pacientes y se consideraban como posibles consecuencias de su personalidad. Por otra parte, las interpretaciones también hacían hincapié en la ambivalencia de los curanderos. En estas historias se entrelazaban las experiencias personales y las circunstancias particulares de la vida de cada uno.

PALABRAS CLAVE: Moralidad. Curación popular. Diagnóstico. Modelos etiológicos. Ambivalencia del curandero.

1 The source material for this article is from Finland, but it represents conceptions of illness and health which were widely held in early modern northern Europe. 


\section{INTRODUCTION}

In this article I will study how people in the early modern age interpreted the nature of illness ${ }^{2}$ and the role that morality played in these interpretations. I begin by examining the significance of the diagnosis for the patient. I also address the question of people's «true nature», or their inner essence, which was an important concept in early modern people's evaluation of someone's morality. I will also shortly introduce two aetiological models (naturalistic and personalistic) used in the early modern age. Then I analyse how diagnoses were reached and how the aetiological models were chosen. Finally, I will study the ambivalent status of the healer as a person who could both help and harm people by using her or his specific skills and powers. Suspicions concerning the healer's real motives arose in circumstances where the healer or healers recurrently failed to heal the patient.

I am not interested in studying illness as a physical or bio-medical phenomenon, but rather as one that is culturally and individually defined and experienced. I suggest that physical symptoms were not as important in the diagnosis as modern people might think. ${ }^{3}$ It seems that physical symptoms were not understood as unchangeable, or they were interpreted liberally. Both aetiological models emphasised the importance of the origin of an illness. They also laid weight on the condition of the patient. Illnesses were understood as strictly connected with the patient's character and were regarded as possible consequences of his personality. ${ }^{4}$

I argue that because knowledge and reality are always cultural and social constructions, many real lives can exist simultaneously. ${ }^{5}$ In other words, it is

2 I use here term «sickness» as an umbrella term covering two sub-concepts: «disease», which refers to bio-medicine and the diagnoses made by educated physicians; and «illness», which refers to cultural interpretations made by patients, their circle of acquaintances or members of their community. KleInMan, A. (1988), The Illness Narratives: Suffering, Healing \& the Human Condition, New York, Basic Books, pp. 3-7; HoNKO, L. (1994), Kulttuuri ja sairaus. In Hyry, K. (ed.), Sairaus ja ihminen, Helsinki, FLS, p. 22.

3 Cfr. Stark, L. (2006), The Magical Self: Body, Society and the Supernatural in Early Modern Rural Finland, Helsinki, Academia Scientiarum Fennica, pp. 275-276.

4 EILOLA, J. (1999), 'Ehkä se on Jumalasta, mutta voi se olla pahoista ihmisistäkin...' Sairauden kokeminen, tulkinta ja parantaminen uuden ajan alussa. In ROIKO-JOKELA, H. (ed.), Vanhuus, vaivat ja erilaiset, Jyväskylä, Kopijyvä, p. 109.

5 Berger, P.L. \& Luckmann, T. (1979), The Social Construction of Reality: A Treatise in the Sociology of Knowledge, Harmondsworth, Penguin Books, pp. 13-17, 33-37; BRUNER, J. (1991), The Narrative Construction of Reality, Critical Inquiry, 18 (1), pp. 18-20. 
possible to reach «reality» only through human experience and interpretation, not through objective self-contained facts. This reality is constructed through the narratives or stories people use to structure and analyse their own experiences and everyday lives, to engage in interaction and to create and reinforce significant normative structures. ${ }^{6}$ From this point of view, illnesses were not only psycho-physical states or subjects for medical diagnosis, they were also subjects for narratives or stories through which people tried to understand what had caused their illness, and why it was happening to them. Here personal experiences and an understanding of one's life situation intertwined. ${ }^{7}$

In focusing on early modern people and their understanding of illness and health, these narrative interpretations between a patient, her or his close friends and the healer are important. In the early modern age, there were not many professional medical doctors in Ostrobothnia or the Åland Islands, which are the geographical areas on which this article focuses. ${ }^{8}$ Those who existed were barber-surgeons or clergymen, whose understanding of illnesses, health and healing did not differ radically from the opinions of so-called folk healers. ${ }^{9}$ They all drew on (folk) tradition, and their relations with their pa-

6 Berger \& LuCKMANN (1979), pp. 35-36; Bruner (1991), pp. 4-7, 10-11, 18-20.

7 This aim to seek explanations for getting ill from one's own personal history is familiar especially in chronically ill patients in our own time. Their interpretation is partly based on experiential knowledge and partly on medical knowledge. It reflects the idea of the "good citizen» whose duty it was to take proper care of her or his own body and personal health. Subsequently, the emphasis on personal responsibility has increased: illnesses are consequences of an unhealthy way of life and personal choices. RAEvaARA, L. (2000), Potilaan diagnoosiehdotukset lääkärin vastaanotolla: Keskusteluanalyyttinen tutkimus potilaan institutionaalisista tehtävistä, Helsinki, FLS, pp. 43-44, 205-215; HONKO (1994), p. 22; GALVIN, R. (2002), Disturbing Notions of Chronic Illness and Individual Responsibility: Towards a Genealogy of Morals, Health: An Interdisciplinary Journal for the Social Study of Health, 6 (2), pp. 109, 112-113.

8 Everyone knew some ointments, herbs and charms which they could use for healing. Besides the folk healers, there were only barber-surgeons, who obtained their education as journeymen and served in the army, or clergymen, who were also thought to have magical power because they dealt with the sacred. In the eighteenth century, clergymen were encouraged to get some basic medical knowledge, and they assisted county barber-surgeons, for instance with vaccinations. SuOlahti, G. (1919), Suomen papisto 1600-ja 1700-luvuilla, Porvoo, WSOY, pp. 223-226; LuUKKO, A. (1945), Etelä-Pohjanmaan historia 3, Vaasa, Etelä-Pohjanmaan historiatoimikunta, pp. 780-781, 783-785; ALANEN, A.J. (1948), Etelä-Pohjanmaan historia 4:1, pp. 319-324.

9 The most important difference was that barber-surgeons used pharmaceuticals not charms in healing. It is questionable whether their understanding of what herbs or minerals to use as remedies or of their healing effects was different from that of the folk healers. They 
tients, in this respect, were very close. They were able to control their patients' conditions and even their hidden conflicts with experiential methods. Their authority stemmed from this cultural identity with their clients and it was not based on an external hegemony. Healers of this kind always treated an illness rather than a disease. In other words, they also took account of religious, moral, economic and communal factors when they diagnosed an illness and tried to remedy it. ${ }^{10}$ Consequently, they made their diagnoses and decisions about their treatment methods on the basis of a dialogue with their patients and their relatives and friends.

There are fundamental differences between narrative and scientific logical argument. The aim of argument and reasoning is to lead to the truth, while the truthfulness of narrative is tested in human interaction. People search for universal truth through logical arguments, while narrative can explain the relationships between different events. Narrative is simultaneously born out of experience and gives it a form. It shapes how one reacts to, and feels about, events. ${ }^{11}$ The narratives related to diseases were not only descriptions of illnesses and their symptoms; they also expressed the morality and the social life of a community. It was primarily a patient's way of life that was evaluated. Questions concerning the healers' morality were more complicated, and they were connected to their ability to offer a culturally and socially acceptable reason for an illness on the one hand and their ability to conduct the process of healing to a satisfactory end for the patient on the other.

Gossiping was a partly invisible but important background factor in the narrative evaluation of morality. Among other researchers who have studied the subject, the anthropologists Van Vleet, Stewart and Strathern have established that evaluating people and moralising about their actions were, and indeed still are, at the very heart of gossiping. Discourses of morality are in-

were all, for instance, aware of the power of mercury; they cupped blood and were familiar with some basic ideas of Galean medicine. As Roy Porter has demonstrated, physicians' attempts to heal patients were more in the nature of theoretical performances and presentations, which had but little to do with diagnosis in the modern sense. PORTER, R. (1999), The Greatest Benefit to the Mankind: A Medical History of Humanity, New York, W.W. Norton \& Company, pp. 40-43; Porter, R. (2001), Bodies Political: Disease, Death and Doctors in Britain, 1650-1900, London, Reaktion Books, pp. 21-26. In this respect, too, they were comparable to the healing performances of folk healers. HoNKO, L. (1960), Varhaiskantaiset taudinselitykset ja parantamisnäytelmä. In HAUTALA, J. (ed.), Jumin keko, Helsinki, FLS, pp. 56-57, 106-108.

10 HONKO (1994), 23-24.

11 BRUNER (1991), 4-7, 10-11, 18-20; OCHS, E. \& CAPPS, L. (1996), Narrating Self, Annual Review of Anthropology, pp. 19-21, 24-25. 
tertwined with culturally located notions of sociality and personhood and historically mediated relationships. ${ }^{12}$

Rumours, in long-lasting network or group contexts, may be stored as information that lies unused for years but remains a resource that can be drawn upon in subsequent situations of change and conflict. ${ }^{13}$ In this article I call this storage of information "social knowledge». It was activated when people fell ill and the healer failed. It is also important to note that without it a healer could not offer a culturally and socially acceptable reason for an illness.

I have used the Records of Dean's Visitations (Åland Islands 1637-1666) and Vaasa Municipal Court Records (1650-1700) as source material. When healers, patients and other interested parties argued in these documents and court records, they had to follow a certain line of reasoning. And they did so publicly. Certainly there was a degree of liberty in the way people could construct their arguments and select the elements with which to build them, but when these elements were incompatible with the basic premises of the contemporary culture, their statements became incomprehensible to others. On the other hand, when contemporaries justified their explanations and stories well, it can be taken as a sign of conformity to acceptable forms of reasoning. ${ }^{14} \mathrm{We}$ can assume that when the court or the Dean and the audience who listened to these stories accepted them or considered them plausible, they represented collectively shared conceptions and beliefs. In this sense, they tell not only of personal experiences but also of collective concepts and values.

\section{THE DIAGNOSIS OF ILLNESS}

A deeper appreciation of the connection between morality and illness requires an understanding of the process of interpretation: how people became convinced that they were ill, and how they explained their illnesses. The natural starting point is that someone feels ill. Becoming ill represented (and it

12 Van Vleet, K. (2003), Partial Theories: On Gossip, Envy and Ethnography in the Andes, Ethnography, 4 (4), pp. 500, 503; Stewart, P.J. \& Strathern, A. (2004), Witchcraft, Sorcery, Rumors, and Gossip, Cambridge, CUP, p. 12.

13 STEWART \& STRATHERN (2004), p. 39.

14 Gijswitut-Hofstra, M., Marland, H. \& De WaArd, H. (1997), Introduction: Demons, Diagnosis and Disenchantment. In GijswiIJT-Hofstra, M., Marland, H. \& DE WAARD, H. (eds.), Illness and Healing Alternatives in Western Europe, p. 1; RoPer, L. (1997), Oedipus and the Devil: Witchcraft, Sexuality, and Religion in Early Modern Europe, London, Routledge, pp. 126-128. 
still does) a crisis for an individual as it affected her or his ability to participate in subsistence activities and ordinary social responsibilities because of malaise, pain, weakness, etc. Moreover, a sick person's expectations concerning the future changed. ${ }^{15}$ Illness causes changes in behaviour and psychological disposition that are health-restoring and rehabilitative (for instance, protecting injured body parts, avoidance of activity, limiting social exchanges, seeking rest and protection). It considerably decreases a person's ability to earn an independent living. This was a critical point especially in the early modern world, where people did heavy physical work, and where the individual contribution of each family member to the household was crucial. Finally, becoming ill caused an individual to be stigmatised by other individuals and his community; in the worst case, it could result in physical isolation from others (in cases of madness or leprosy and other infectious diseases). ${ }^{16}$

Different diagnoses of illness had different consequences, which influenced both the behaviour of the sick person and the relationships between her or him and the wider community in several ways:

1) The diagnosis gave a person the right to act like a patient: it freed her or him from certain everyday routines and responsibilities. ${ }^{17}$

2) The diagnosis stigmatised a person as someone who was not a fully productive member of the community. ${ }^{18}$

3) It also gave hope of recovery in the future. ${ }^{19}$

A sick individual could not diagnose her- or himself (in isolation), and s/he therefore needed cultural knowledge or had to consult a rite specialist. Collective interpretations of the aetiology of illnesses were often, in fact, expressions of

15 SoIVio, J. (1996), Sjukdomsupplevelsen som en berättelse med två röster, Nord nytt, 64, p. 58; FABREGA, H.Jr. (1997), Earliest Phases in the Evolution of Sickness and Healing, Medical Anthropology Quarterly, 11 (1), p. 29.

16 Honko (1960), pp. 55-56, 84-85; KleinMAN (1988), pp. 4-7; VilKunA, K.H.J. (1996), Kun hullujenhuoneelle kerran joutuu, ei poispääsyä ole: Mielenheikkous, kehitysvammaisuus ja tartuntavaara 18. vuosisadalla. In RoIKO-JOKELA, H. (ed.), Kirkonkirjat paikallis-yhteisön kuvaajina, Jyväskylä, Kopijyvä, pp. 214-216, 221-225, 231-233.

17 RØRBYE, B. (1980), Allmän etnomedicinsk översikt. In Botare: En bok om etnomedicin $i$ Norden, Stockholm, Lts Förlag, pp. 172-173.

18 VilKunA (1996), pp. 214-215, 226-230.

19 HonKo (1960), pp. 84, 96-97; RøRBYE (1980), pp. 188-191. 
collective morality. ${ }^{20}$ Early modern folk medicine emphasised the importance of establishing the origin of a disease for the following reasons:

1) It was believed that a healer could exert power over an illness by naming its «parents».21

2) The healing method chosen depended upon the origins of an illness. ${ }^{22}$

3) An individual's moral responsibility for her or his condition was evaluated in light of the origin of the illness. ${ }^{23}$

A healer worked out the origin of an illness ritually. Henrik Jakobsson Pohjalainen (from Mustila in the parish of Isokyrö), for instance, could divine from the surface of a filled drinking bowl what had caused an illness. He was not willing to give a more detailed explanation of how he worked. ${ }^{24}$ As scholars have pointed out, in such cases the healers had already made their decisions before they performed the ritual. They based their interpretations on social knowledge and aetiological models. ${ }^{25}$ In this respect, the interpretation process was bi-directional on different levels. First, the interpretation of the cause of an illness had an effect on the evaluation of the moral responsibility of a sick person and vice versa. Second, the individual experience of illness and explanations of the causes on the one hand and the collective interpretation process on the other shaped one another. The interpretation was performed ritually because only then did it become «sacred» and conclusive. Rites connected the interpretation to the other world and gave it an authority and strength which would have been difficult to achieve by any other means. ${ }^{26}$

20 Honko (1960), pp. 56-57, 97-99; KleinMan (1988), pp. 5-6; FABreGa (1997), pp. 30, 31.

21 SiIKala, A-L. (1994), Suomalainen šamanismi - mielikuvien historiaa, Helsinki, FLS, pp. 77-81.

22 Manninen, I. (1933), Kansanomaisesta tautiopista ja taikaparannuksista, Suomen kulttuurihistoria 1, Jyväskylä \& Helsinki, Gummerus, pp. 238, 240.

23 PORTER (1999), pp. 84-87, 110-111.

24 Kansallisarkisto (KA, Helsinki): Vaasa Municipal Court records (VMC) 22.8.1657.

25 Honko (1960), pp. 85-86, 95-96; Macfarlane, A. (1970), Witchcraft in Tudor and Stuart England: A Regional and Comparative Study, London, Routledge \& Kegan Paul, pp. 109-113, 122-124; Miller, I.A. (1986), Dreams, Prophecy and Sorcery: Blaming Secret Offender in Medieval Iceland, Scandinavian Studies, 58 (2), pp. 106-109; FABREGA (1997), p. 31 .

26 Douglas, M. (2000), Purity and Danger: An Analysis of Concepts of Pollution and Taboo, 2nd edition, London, Routledge, pp. 70-73. 
There were two different aetiological models which offered explanations of the causes of illness: naturalistic and personalistic (ailments sent by God, other supernatural beings or an evil person), although in practice these models which were not so clearly differentiated from each other. ${ }^{27}$ Questions about the connections between morality and the causes of illness were present in both of them. This was most evident in the case of diseases sent by God, which could be understood as either a punishment for sin or God's gift through which $\mathrm{He}$ tested the strength of a believer's faith. A patient could only repent his sins and pray for forgiveness from God. The Church emphasised that the healing of the body could only begin if the soul was first purified. ${ }^{28}$

The second group of illnesses in the personalistic model comprised those sent by an evil person, usually a witch. It is important to notice that in these cases the evaluation of the moral state was not restricted to the patient but also to the suspected witch. In the Finnish source material, the ailments were usually caused by curses.

The naturalistic model explained healthiness as an equilibrium of the basic elements and fluids in the human body. This model, which we can find expressed in seventeenth- and eighteenth-century guides to health and longevity, emphasized the need to regulate all those aspects of life that a prudent man or woman could control: diet, exercise, sleep, the «evacuations», and emotions. In the terminology of the day - and following a tradition that could be traced back to Hippocrates and Galen - such factors were termed the «nonnaturals» (as opposed to the «naturals»), innate factors that might also lead to disease. It is obvious that such concern with day-to-day routine provided an occasion to reinforce society's behavioural norms; there could be no practical distinction between the realms of morality, meaning, and mechanism. ${ }^{29}$

Even though the causes of illnesses were understood differently, there were no clear differences in symptoms between, for instance, a disease sent by God and a natural illness. Of course, leprosy was usually strongly associated

27 PORTER (1999), pp. 33-35; LÖFGREN, O. (1991), Lyckan och avunden. In STATTIN, J. (ed.), Det farliga livet. Om avund, rädsla, rykten och fordomar, Stockholm, Natur och kultur, pp. 93-96.

28 PORTER (1999), pp. 84-87, 110-111; JUVA, M. (1955), Varsinais-Suomen seurakuntaelämä puhdasoppisuuden hallitsemina vuosisatoina (1600-1808), Turku, Varsinais-Suomen Historiantutkimusyhdistys, pp. 63-64.

29 PORTER (1999), pp. 9, 39, 56-61, 75-77, 115-116, 173-175; ROSENBERG, C. (1997), Banishing Risk: Continuity and Change in the Moral Management of Disease. In BRANDT, A.M. \& Rozin, P. (eds.), Morality and Health, New York, Routledge, p. 36. 
with God's wrath, ${ }^{30}$ but people did not draw that conclusion automatically. The interpretation of the cause of illness was always connected to the individual's personal situation and the norms and values of the surrounding social network. Social knowledge had a crucial role in this aspect of interpretation.

It is important to note that early modern Finns thought that a human being had some kind of inner essence which they referred to as «luonto» (nature) and «laatu» (quality). ${ }^{31}$ An individual's characteristics were intrinsically connected to this inner essence that defined her or his identity. The inner essence had certain qualities. First, it was difficult to change or transfer. However, one can say that a good nature could turn into an evil nature more easily than an evil nature could become good. It was also possible for the inner essence to be transferred through infection or inheritance. Therefore it was believed that maliciousness or magical powers could be passed from a mother to her daughter or from a father to his son. 32

This kind of essence was a necessary concept because it permitted individuals to anticipate the actions of others with only meagre information at their disposal. This is closely connected to the "pre-anatomical» understanding of corporality. A body was not a site of predictable processes but rather of sudden changes. There was always a danger that negative inner feelings (which by their nature were difficult to control and check), like anger and envy, could erupt. Boundaries between the internal and the external, the individual and the social, and the emotional and the physical were generally experienced as permeable, not tight. Therefore social and emotional experiences could directly affect the inner flow of the blood, for example. Furthermore, hidden hatred or envy could harm people and might even find expression in apparently innocent wishes of good luck. Early modern people thought that external ac-

30 PORTER (1999), pp. 84-87, 121-122.

31 The noun «luonto» (nature) is a derivative from the verb «luoda» (create). It has many meanings and synonyms. It can refer, for example, to the physical environment, to a human body or to a person's inner essence. PIELA, U. (2006), Luonto ja muuttuvat maailmat kansanlääkinnässä. In Helsti, H., Stark, L. \& TuOMAala, S. (eds.), Modernisaatio ja Kansan kokemus Suomessa 1860-1960, Helsinki, FLS, p. 280. Christfrid Ganander compiled some examples of the last-mentioned use in his dictionary (1787): «luodut kaikki katoavat laatuinensa luondoinensa» (all creatures will disappear with their qualities and natures), «kyllä luondo luoxe tuopi, weri wjerellen wetääpi» (for sure, nature summons, the blood attracts), «minun luondoni turmeldu on Adamin vijan tähden» (my nature is corrupted by Adam's original sin). GANANDER, C. (1997), Nytt Finskt Lexicon 1787, Helsinki, FLS, laatu [11496], luoxe 1. luoxi [13784], turmelen [27139].

32 PyYsläInen, I. (2005), Synti. Ajatuksin, sanoin ja töin, Helsinki, WSOY, pp. 24-26; PIELA (2006), pp. 283-284. 
tions should openly reflect positive inner feelings. They also believed, conversely, that it was possible to control inner feelings by regulating external behaviour. ${ }^{33}$ This, however, was only an ideal situation which did not necessarily have a counterpart in reality. Therefore it was important to know what kind of inner essence or nature certain people had.

When people tried to evaluate the moral state of a sick person and her or his inner essence, they used their social knowledge. This knowledge was accumulated by gossiping during informal gatherings or when people talked while they were working. ${ }^{34}$ These conversations shaped interpretations in two different ways. First, a community's existing knowledge of an individual's behaviour, affected its interpretations of her or his present behaviour. Second, observations of present behaviour might alter existing interpretations of past behaviour. It was naturally more difficult to evaluate the natures of strangers because they were unknown to the community. In principle, strangers could create whatever identity they wished to adopt. ${ }^{35}$

This also means that diagnosing and understanding the cause of sickness were closely connected to the patient's situation in life. They not only included the bio-medical causes of the ailment, but they also took into account the patient's social behaviour.

There were also cultural models or stereotypes which people used when they tried to judge the inner essence of a fellow human. First, there was the ideal of the good Christian, whose essential characteristics were her or his love and solicitude. S/he took care of the poor, helped her or his neighbours and was hospitable to other people. This idea was closely connected with the Table of Duties, a collection of quotations from the Bible in Martin Luther's catechism. The table described how the inner hierarchy of a household should be ordered. It detailed how a man ought to behave in order to be a proper master of a household, husband and father. It also defined women's roles and behaviour as daughters, housewives, wives and mothers. The Table of Duties emphasized the virtues of love and charity, fairness and obedience. ${ }^{36}$ Lutheran

33 Stark (2006), pp. 158-162, 254; Rublack, U. (1996), Pregnancy, Childbirth and the Female Body in Early Modern Germany, Past \& Present, 150, pp. 93-94, 109; RoPer (1997), pp. 20-26; PORTER (1999), pp. 38-40.

34 VAn VleEt (2003), pp. 493-494, 496-497, 499-501.

35 EILOla, J. (2003), Rajapinnoilla: Sallitun ja kielletyn määritteleminen 1600-luvun jälkipuoliskon noituus- ja taikuustapauksissa, Helsinki, FLS, pp. 266-269.

36 StADIN, K. (1998), Hade svenska kvinnorna en stormaktstid? Stormaktstidens svenska stat och konstruktion av genus, Scandia, 63 (2), pp. 207-211; BERGNER, B. (1997), Dygden som levnadskonst. Kvinnliga dygdeideal under stormaktstiden. In ÖsterberG, E. (ed.), 
clergymen, among them the Bishop of Turku Isak Rothovius, wrote that if the roles and relationships between the members of the household were properly ordered, the whole of society would be well ordered and functional. If proper order was not established, Rothovius wrote, there would be no respect for the priests or the authorities, and everyone would behave just as they wished. The most important social roles, therefore, were based on the Table of Duties. ${ }^{37}$

The seven deadly sins were another, older, set of ideals that defined the proper Christian. These sins were not offences but rather characteristics. They were acts of misconduct not against God but against other fellow human beings. The seven deadly sins were also at least partly sentiments. In fact, they formed the basis of a taxonomy of sentiments that people used when they classified a feeling as either permissible or forbidden. Feelings such as hatred and envy, which were often prominent in witchcraft cases, were prohibited. People did not wish to recognise these sentiments in themselves, and therefore they were often denied or repressed. ${ }^{38}$

The Lutheran Church also taught that continuous wars, recurrent epidemics and famines were signs of God's anger at the sins of the people. It was believed that the sins were committed by individuals, but that God's punishment was collective. The sinners had to be found, punished and encouraged to repent and change their behaviour, because only in that way might God be persuaded to relent. ${ }^{39}$ What then were these sins that had been committed? They were, of course, transgressions of God's commandments, but also violations committed against the Crown and the Church, which were the channels of God's power. Breaches of the orders in the Table of Duties were also labelled as sins.

The fear of sin and collective punishment inspired feelings of guilt, impurity, and failure. Fear also strengthened the desire of the righteous to band together and to single out the sinners. As a result, people closely watched the behaviour of others and tolerated no deviations from the collective norms. In

\footnotetext{
Jämmerdal och fröjdesal: Kvinnor i stormaktstidens Sverige, Stockholm, Atlantis, pp. 80-82; JOHANSSON, K. (1997), Mannen och kvinnan, lusten och äktenskapet. Några tidtypiska tankegångar kring gåtfulla ting. In ÖSTERBERG, E. (ed.), Jämmerdal och fröjdesal: Kvinnor $i$ stormaktstidens Sverige, Stockholm, Atlantis, p. 43.

37 PARVIO, M. (1959), Isaacus Rothovius, Turun piispa, Turku, FSCH, p. 217.

38 JuVA (1955), pp. 62-64; RoPer (1997), pp. 22-24; FlynN, M. (1998), Taming Anger's Daughters: New Treatment for Emotional Problems in Renaissance Spain, Renaissance Quarterly, 51 (3), pp. 868-872; GREgORY, A. (1991), Witchcraft, Politics and 'Good Neighbourhood' in Early Seventeenth-Century Rye, Past \& Present, 133, pp. 34, 54-58.

39 JUVA (1955), pp. 62-65.
} 
practice this meant —as Alan Macfarlane (1970) has noted - projecting one's own sins onto others and seeking out scapegoats.

\section{From NATURAL ILLNESS TO DISEASE SENT BY GOD}

A certain Karin from Nordanberg in the Åland Islands complained to Dean Boetius Murenius that during the previous Sunday's divine service a man called Michel from Jösselbo had slapped her with his glove. At that moment, she had felt a terrible pain as though someone had stabbed her with a knife, and she had not yet fully recovered from her headache. Michel claimed that Karin had whispered and talked continuously with the porter's wife throughout the divine service, especially while the priest was reading the invocation. He had tried to ignore the chatter for some time before he rose from his own pew, lightly slapped Karin with his summer glove and asked them both to be quiet. ${ }^{40}$

In the interpretation of this case, there are several arguments that are based in morality. First, it was believed that even a light slap could cause considerable pain if it was unjustified. This was exactly what Karin complained about: she had sat down, and Michel had hit her without any reason. However, it was the community who would ultimately decide if the slap was justified or not. Murenius discovered that Karin had not only spoken during the sermon, but that she had also taken a seat that was not her own. Witnesses also testified that Karin was not only ungrateful to people who had given her alms but had, in fact, picked fights with them. As a result, in the parishioners' view she had earned her headache because of her improper behaviour. In fact, a local sheriff alleged that Karin had complained of a headache even before the divine service. Karin did not deserve compassion because her ailment was interpreted as being a just punishment for her deviant behaviour. ${ }^{41}$

Moral judgements are even more evident in the case of one Margareta Henriksdotter. She had grown up in the town of Vaasa, where the townspeople knew that she had suffered from epilepsy from an early age. Her father went to the Municipal Court and described how Margareta's life had become so miserable that she should be sent to a hospital. The problem was that he was not wealthy, and therefore he had to ask for financial assistance from the

40 Murenius, B. (1905), Acta Visitatoria 1637-1666, Helsinki, FSCH, pp. 136-137 (Sund 2.2.1646).

41 Eilola (1999), p. 110; JüTTE, R. (1994), Poverty and Deviance in Early Modern Europe, Cambridge, CUP, pp. 9-12. 
other townsmen. The magistrate advised that there would be no problem, and that in this instance he could have all the money he needed. ${ }^{42}$ No references were made to Margareta's way of life or her morality. It seems that people accepted her epilepsy as a natural illness or a trial from God. On the other hand, it is possible that Margareta's life was miserable because she was seen as a deviant individual whose outward appearance (and behaviour) was damaged by her illness, and the community would be glad to see her removed from its midst. 43

Some years later, the tone of the court record is totally different. "Then the Court interrogated Margareta Henriksdotter about rumours concerning her wanton way of life, claiming that God had punished her with two shameful diseases, to wit epilepsy and syphilis.» ${ }^{44}$ It seems that her contraction of syphilis together with her way of life had changed the community's understanding of the cause of her epilepsy. People did not think of it anymore as an illness but rather as a punishment.

What had Margareta done then? She had been summoned to the court because she was accused of intimacy with a married man. Rumours prompted questions about other lovers to be raised in the court. Margareta admitted that she had had other lovers and named several leading townsmen. These men made written depositions. These emphasized the polarity between Margareta and the writers, namely the gulf between the ignorant and the educated, and the dishonourable and the honourable. Thus we can read how, for instance, Treasurer Petter Wilstadius complained «with shed tears» about «the malicious and false accusations of this dishonourable, poxy and filthy bitch». The depositions also include information about her way of life and her earlier conflicts with others, which makes it easier to comprehend the change in the court's attitude towards her illness. The court records detail a long list of her everyday moral transgressions. Margareta was shown to have lived a wanton life: she drank, pilfered and swindled. She was also idle and readily cursed other people. She was disobedient to the authorities and showed no respect to her own parents. In fact, several times Margareta had tried to kill both her sister and her mother, as their neighbours had testified. She had also tried to drown herself, which was interpreted as a sign of weakness in the head. Margareta was furthermore guilty of practising magic and superstition, and she

42 KA: VMC 14.4.1686.

43 RUBLACK (1996), pp. 96-97; VILKUNA (1996), pp. 229-230.

44 KA: VMC 14.9.1691. 
did not usually attend divine service. ${ }^{45}$ The latter point was important because divine service, and especially the Eucharist, was considered to be one of the most important ways of strengthening the coherence of the community. Those who did not participate in Holy Communion had either been excluded from the community or had chosen to remain outside it. 46

Margareta gave her own account of how she had contracted syphilis. She told the court that one evening Petter Wilstadius had knocked on her window. She went outside, where Wilstadius made her an offer: if she slept with him that night, she would receive a dress. They then went together to Wilstadius' garden, where he left her in one of his outbuildings and went into the main building. He returned later, and they had sex. Margareta told the Municipal Court something strange, namely that during their encounter Wilstadius had inserted something inside her. She could not be sure exactly what he had inserted but they reminded her of white pearls. However, Margareta was sure that, whatever these «pearls» were, it was they that had caused her syphilis. ${ }^{47}$

Margareta's case demonstrates that morality and trust were considered to be closely connected with social status. Wilstadius had an established position in the community and commanded respect, in contrast to Margareta, who, in addition to her low social standing, was also burdened with a bad reputation. Therefore she stood little chance of being believed even if her story was true (which we cannot establish).

I believe that there were two main reasons why the townsmen changed their opinions about the cause of Margareta's epilepsy, and why they no longer wanted Margareta to live in the community. The accusation of adultery gave the townsmen an opportunity to interfere in her life to a greater extent than before. However, I think that Wilstadius' claim that Margareta's behaviour became more disruptive as she grew older may be more significant in explaining the change in the townsmen's attitude. The community may have understood that children did not behave (or could not be expected to behave) like adults, and so they overlooked her behaviour as a child. ${ }^{48}$ Equally, Mar-

45 KA: VMC 19.9.1691.

46 JuVA (1955), pp. 107-110.

47 KA: VMC 14.9.1691.

48 The idea of a life span strongly determined common expectations concerning the course of human life. These expectations were not same for boys and girls. Children were regarded as innocent on the one hand but on the other as especially exposed to the temptations of evil. Parents did their best to protect small children from dangers. Socialisation into the social roles of adulthood began at the age of ten, when children began to take part in adult tasks and duties. Thus adulthood was more question of «maturity» than a biological age. Maturity was 
gareta's behaviour could represent the frustration of someone who suffered from a chronic condition which was channelled into conflicts with others. ${ }^{49}$ Also the fact that Margareta remained in the town even though the townspeople had collected money to send her to hospital would not have increased her popularity among them.

\section{ILLNESSES SENT BY WITCHES AND OTHER EVIL PERSONS}

No-one was surprised when a man from Vaasa called Peder Thomasson died there in December 1664. He had fallen ill some months earlier, and people had seen him getting worse every day. Then, soon after his death, his widow and some other relatives came before the Municipal Court and accused Gertrud Nillsdotter, a hatter's wife, of witchcraft. There was a large body of evidence against her. During the trial that followed, the members of the Municipal Court discovered that there had been two diagnoses of the causes of Peder's illness. A group of magistrates and other «upright men» who had examined the body said that the cause was witchcraft. On the other hand, the barber-surgeon thought that Peder's death had been caused by gangrene. He said that Peder had not sought his assistance early enough, and therefore he had been unable to help him. ${ }^{50}$

The diagnosis of the magistrates and «upright men» is more interesting. They had examined the body and found black spots in the same places where

understood as the ability to earn one's living and to take care of one's family. Thus it was strongly connected with marriage. BERGNER (1997), pp. 76-77, 85-86, 98-100; VILKUNA, K.H.J. (2004), Lapsuuden ja puolikasvuisuuden kynnyksellä. In AHONEN, K. et al. (eds.), Toivon historia, Jyväskylä, Dept. of History and Ethnology, pp. 23-28; HEYWOOD, C. (2006), A History of Childhood, p. 40.

49 Recent studies of chronic illness have shown that especially during the early phase of their illnesses patients are frustrated by their disability and have not accepted its impact to their lives. Later these feelings may yield to acceptance or to resignation, depression, anger and feelings of hopelessness. These studies also suggest that feelings of frustration and upset connected with the development of the self and one's relationship with other people and the wider environment are more common among older adolescents that younger children: their peers tease them, adults insist on compliance with expected behaviours, all of which are deemed «unfair to me». See, for example, LeIFER, R. (1996), Psychological and Spiritual Factors in Chronic Ilness, American Behavioral Scientist, 36 (9), pp. 753, 759, 763-764; THIES, K.M. \& WALSH, M.E. (1999), A Developmental Analysis of Cognitive Appraisal of Stress in Children and Adolescents with Chronic Illness, Children's Health Care, 28 (1), pp. 16-17, 25-27, 28-29.

50 KA: VMC 12.10., 14.12., 17.12.1664, 16.1.1665. 
Peder had struck Gertrud. They also knew that Gertrud had magical powers, and that her mother had been given a fine for practising magical healing almost ten years earlier. This supernatural power was believed to be morally neutral. ${ }^{51}$ Someone who possessed the power could use it for either good or evil. The Court focused their attention upon Gertrud's character. She had feuded with her neighbour Peder, and she had cursed him several times. Soon afterwards Peders's dog had fallen ill and lost its appetite. Because of the close relationship between a dog and his master, ${ }^{52}$ it was easy to assume that the dog was suffering from an ailment that was destined for its master. These ideas were reinforced when Peder fell ill and the dog simultaneously recovered.

There was also a moral judgement in this interpretation. Peder and Gertrud had previously gone before the Municipal Court to reconcile their disagreement. ${ }^{53}$ The litigants shook hands and peace and harmony was apparently restored. However, when Gertrud left the courtroom, she again cursed Peder and behaved as though there had been no reconciliation between them. This was a very serious transgression of social norms because reconciliation was one of the most important ways of dealing with conflict within the community. As long as reconciliation worked, it was possible to maintain and even strengthen the coherence of the community. The failure of this process and the undermining of court rulings would end in chaos and anarchy. When Gertrud accepted reconciliation before the court but later rejected it, she was also denying the authority of the court and its decisions. Now she was a threat not only to Peder and his family but to the whole community. This kind of reaction against those who reneged on reconciliation is also evident in other witchcraft cases. Furthermore, troublemakers who feuded with everyone and who could not keep up the reconciliations they had made were thought to have an evil nature. Therefore, a community would be glad to see the back of such deviants one way or another. ${ }^{54}$

The Municipal Court could not decide which explanation of the cause of Peder's death was correct. Therefore Gertrud was ordered to swear an oath

51 Klaniczay, G. (1993), Hungary: The Accusations and the Universe of Popular Magic. In Ankarloo, B. \& Henningsen, G. (eds.), Early Modern European Witchcraft: Centres and Peripheries, Oxford, Clarendon Press, pp. 240-243; ClARK, S. (2002), Witchcraft and Magic in Early Modern Culture. In Ankarloo, B. \& Clark, S. (eds.), Witchcraft and Magic in Europe 4: The Period of the Witch Trials, London, Athlone Press, pp. 112-113.

52 Rogers, K.M. (2005), First Friend: A History of Dogs and Humans, New York, St. Martin's Press, pp. 88-96.

53 KA: VMC 21.10.1661, 12.10., 15.10.1664.

54 Eilola (2003), pp. 270-279. 
that she was innocent. She also had to find twelve respectable and reputable persons who would confirm her oath. By doing so, the Court left the decision to public opinion: if people believed that she was innocent, she should have little difficulty in finding people who would corroborate her oath. Public opinion judged Gertrud to be guilty, however, and she failed to find enough people to support her even though the Municipal Court extended her deadline. ${ }^{55}$

\section{WHEN HEALERS FAILED}

County Barber-Surgeon Petter Watz complained in Laihia Rural District Court that a tailor called Matts Johansson had several times practised his business. The latter had, for instance, treated a man who had breathing difficulties and ordered him on the first occasion to snuff tobacco and cloves and on another occasion marjoram and ginger. Another patient explained that she had sought Watz's care several times but that the cures he had prescribed did not help. When her condition worsened, she decided to ask for Matts' help. ${ }^{56}$ This case indicates that there existed a medical market. It can be understood as a forum where knowledge was presented and demonstrated. The word «market» emphasises the relations of exchange between healers and their clients on the one hand and the competition between healers on the other. ${ }^{57}$ From the patient's viewpoint, it was important that the treatment was as efficacious and satisfactory as possible. There were, then, several different health care systems in society from which a patient could choose. ${ }^{58}$ In the early modern period, patients had even greater freedom to choose because none of these systems had an absolute monopoly. On the contrary, it seems that people moved quite easily from one system to another.

Truth is very much a matter of trust. What people believed to be true depended to a large extent on their trust in the people who made or supported particular claims to knowledge. Trust engendered states of «belief», which can be understood as assent to these claims. ${ }^{59}$ If we think of healing as a rite,

55 KA: VMC 16.1.1665.

56 Alanen (1948), p. 319.

57 The concept of the medical market can be used as a heuristic device for mapping the interaction between the supply and demand for all kinds of medical services in a particular region and at a particular time. GIJSWIIJT-HOFSTRA, MARLAND \& DE WAARD (1997), pp. 10-11.

58 HONKO (1994), pp. 14-15, 18-19.

59 GiJswiJj-Hofstra, MARLAND \& De WAARD (1997), pp. 8-9. 
it was important that a patient and her or his closest relatives and friends trusted the healer because otherwise the process of healing was not possible. Klara Göransdotter Lyttraeus, the widow of the Vicar of Vaasa, together with her daughter and a trusted servant girl asked one Valborg Pedersdotter Kokkoinen to heal her illness. One night Valborg came to the parsonage and performed certain rites. Among other things, she read some prayers over a piece of bread and moved it three times around the widow's head. In this way she transferred the illness to the bread. It was then given to a servant girl because the widow thought that she had been bewitched. The servant girl ate the bread and soon fell ill. ${ }^{60}$

The healer had to be able to respond to expectations about the methods a «proper» healer used and the basis on which s/he worked. A community and its members had an opinion about right and wrong methods, and these varied. ${ }^{61}$ The widow's case shows how commonly held opinions could be in conflict with personal choices. As we saw earlier, people asked healers to name the person who had bewitched them. The authorities and clergy did not necessarily accept healing methods in which God's name was improperly used, but they did not have anything against healing in principle. However, there was a boundary that might not be crossed. And sending an illness back to its original sender as an act of revenge crossed this boundary. The reason is clear: it was thought that a healer could make a mistake about who the witch was and thus send the illness back to an innocent person. ${ }^{62}$

In principle, there were no incurable illnesses in personal aetiology. Because an illness was always caused by someone, it was possible to find her or him. This could lead to problems when a healer or healers recurrently failed to help their patient. The case of Matts Mårtensson's family illustrates these problems. Matts had suffered from chest pains since January 1657, and he was confined to bed for the first time at Candlemas ( $2^{\text {nd }}$ February). The other members of family fell ill at Easter, when Matts first sought help from healers and travelled to Stockholm to buy some medicines. A little bit later one of the children died. The first «creatures» came out of Matts in May. Some of them looked like «eggs», and some others were like worms with heads and eyes. Matts finally died in August or in September. There were several attempts to explain and cure the family's illnesses. ${ }^{63}$ They constitute the following chain of events:

\footnotetext{
60 KA: VMC 11.4., 13.4.1663; HoNKO, L. (1960), pp. 73-75.

61 HONKO (1960), pp. 83, 87-93.

62 HoNKO (1960), pp. 75-77, 94-95.

63 KA: VMC 1.8., 5.10., 7.10.1657.
} 
1) Matts and his wife Kirstin Rolofsdotter sought help from one Henrik Jakobsson Pohjalainen, who visited in their house at Easter. On that occasion he said that the whole family was cursed. He made his next visit in June, when he saw from the surface of water in a bowl that the family had been cursed by a certain Margareta Parkoinen. He did not even try to cure the family. He made his decision after listening to what people thought. First he sought out the opinions of the members of the family and their close relatives and friends. Then he investigated whether the person they suspected was widely known as a witch. Parkoinen indeed had such a reputation, and therefore on his second visit he was able to denounce her. ${ }^{64}$

2) Margareta Parkoinen tried to save herself. She offered warm beer to Matts Mårtensson's wife Kirstin and washed her hair with salt water on the same day that Pohjalainen accused her. She was successful, because a little later Kirstin expelled from her body with great pain four creatures that resembled worms or frogs. ${ }^{65}$ The conception of an illness as a worm or a frog which had intruded inside a human body is a global one. Gillian Bennett, who has studied the matter in western Europe, suggests that these stories reflect fears of accidentally swallowing frog-spawn. They also reflect the prevalent living conditions, where it was difficult for people to get clean water, which meant that there could be anything in the water they drank. ${ }^{66}$ The third and probably most comprehensive explanation for these stories is intestinal parasites. ${ }^{67}$ Earlier worms with heads had come out of Matts, so probably Parkoinen assumed that his wife had the same illness. Perhaps Kirstin also felt them moving inside her and her stomach rumbled - both were typical symptoms in cases of this kind - but there is no mention of this in the court records. Parkoinen tried to drive the creatures out of Kirstin by giving her warm beer with salt. The collectively shared idea was that these creatures ate and drank the same food and drink as their hosts did. If they did not taste good, creatures would be expelled. ${ }^{6}$

Then a difficult question arose: how had these creatures come into Kirstin's belly? Parkoinen tried to explain that the cause of Kirstin's illness was a

64 KA: VMC 8.6., 22.8.1657.

65 KA: VMC 8.6.1657.

66 BennetT, G. (1997), Bosom Serpents and Alimentary Amphibians: A Language for Sickness. In Gijswitut-Hofstra, M., Marland, H. \& De WaArd, H. (eds.), Illness and Healing Alternatives in Western Europe, London, Routledge, pp. 227-228.

67 HONKO (1960), pp. 80-81.

68 BENNETT (1997), pp. 228-229. 
natural one: there had been frog-spawn in her drinking water. The servant girls who had brought water to Kirstin testified that the water had always been clear. People became more and more convinced that the cause was, indeed, witchcraft, and when a certain Klara Göransdotter ${ }^{69}$ related that she had heard Parkoinen curse Kirstin with the words: "In this world you will melt as butter in a pot.» A little after that Kirstin fell ill.

3) Margareta Parkoinen said that she might have been able to cure Kirstin, but that she failed because a certain Margareta Rödfinska came to the house and tried to cure her by giving her spirits. When Matts fell ill in January, he had asked Rödfinska for help. She had given him two complex sets of instructions. First she told him to go into a forest where there were a lot of rowan trees. $\mathrm{He}$ was to bend one of them over and weigh it down and then crawl under it three times anticlockwise. Then he was to collect bark from nine trees, boil it in water and drink the water. Finally he must make a tunnel and crawl through it three times. Then, when Matts' condition became worse, she said that he should make a mixture of three different kinds of spirits and heat it up with a special kind of stone before drinking it. Then he should take a piece of red cord and go with it to the seaside. There he should make nine knots on it and then throw it over his left shoulder so that the north wind could take it. Finally he should take a water jug that stood to the south of him and let his wife drink from it. When Kirstin Rolofsdotter told this in the court room, Rödfinska corrected her and said that she should have washed the illness out of Matts with the water, not drunk it. ${ }^{70}$

Finnish folk medicine uses the terms «nenä» and «vihat» as collective names for several different illnesses caused by «väki» (mana-like dynamistic force). What connected them was the idea that they could be transmitted by a careless touch, for example from forest, fire, water, soil or air. ${ }^{71}$ It was important to discover the source of Matts' illness because the best way to heal him was to put him in touch with the origin. If it was impossible to find out the source, a healer could involve several of them in the treatment. That is what Rödfinska did. When she told Matts to make a tunnel, she apparently thought that the illness might have come from the soil. When she ordered him to throw a piece of cord into the wind, she seemed to think it might be the air that had caused it. There were also other magical and mythical elements and meanings in her precept. The cord was to be thrown into the north wind be-

69 Klara Göransdotter is not the vicar's widow but the mother of Gertrud Nillsdotter, the hatter's wife, mentioned earlier in the article.

70 KA: VMC 8.6., 1.8.1657.

71 STARK (2006), pp. 258-262, 269-277. 
cause the mythical home of all illnesses was believed to be in the north. The idea of the knots was to bind the illness to the cord, a method that was widely used in northern Europe in the early modern age. The numbers three and nine were believed to be powerful, and they were typical in charms. ${ }^{72}$

Suspicions concerning Rödfinska's motives arose. Margareta Parkoinen said that she had killed Matts with witchcraft because they had had some disagreements in January. One day Rödfinska had come to Matts' house. The master of the household was then lying on the bed. Rödfinska sat beside it and when she talked with Matts, she put her hands on his chest. The pains in his chest began some time later. These suspicions had probably originated from Matts' house. One of his neighbours had advised him to seek help from Rödfinska because if she had caused the illness, she would be able to cure it. ${ }^{73}$

There were also other factors that sullied Rödfinska's reputation. There were rumours that she went around begging from house to house, and it was said that, if she did not get what she wanted, she cursed people, with the result that accidents often followed. Some peasants had made a complaint about her to Chaplain Jakob Vasenius earlier in 1655. Since then Vasenius had worked against her and denounced her publicly as a witch on Epiphany 1656. He had also prosecuted her in the court, but he had suddenly died one day before the case was due to be heard. An assessor from the Turku Court of Appeal who examined his body said that there was a small white mark in his chest. He concluded that witchcraft was the cause of the chaplain's death. ${ }^{74}$

4) When things seemed to be turning against her, Margareta Rödfinska changed her strategy. She followed the same model of behaviour as Pohjalainen had done. She used liquor to divine that Matts' family and everything they owned was cursed. Then some time later, she also denounced the witch. One morning she met Matts' mother, Dordi Månsdotter, and said to her: «Because I have met you now, I have lost all my power.» She had chosen her target well. Dordi had had disagreements with her son and especially with her daughter-in-law. She had also cursed them with the words: "God curse my son and his wife as they have cursed me.» There were also rumours that Dordi had paralysed one woman and made another ill by cursing them. ${ }^{75}$

72 Honko (1960), pp. 83-84, 93; MANNINEN (1933), pp. 232-233, 235, 238-241, 244; SIIKALA, A-L. (1994), pp. 77-82.

73 KA: VMC 8.6., 1.8.1657.

74 KA: VMC 12.11.1655; 23.1., 21.5., 31.5.1656; 6.7., 1.8., 3.8., 22.8., 17.9.1657.

75 KA: VMC 1.8., 5.10., 7.10.1657; HertZBERG, R. (1889), Bidrag till Finlands kulturhistoria på 1600-talet: Vidskepelse, Helsinki, Hufvudstadsbl. Nya Tryckeri, pp. 101-102. 
5) Klara Göransdotter came under suspicion, and she was interrogated in 1658 on the orders of the Turku Court of Appeal. She had earlier testified that Parkoinen had put a curse on Kirstin. Now she said that Parkoinen had also asked her for help. She emphasised that she had been the one who had driven the creatures out of Kirstin's belly by giving her liquor with salt. She had not caused her illness with witchcraft. ${ }^{76}$

As Stewart and Strathern point out, it was extremely common for witches to confess and accuse one another; these represented attempts by the accused to deflect blame or obtain pardons for themselves. ${ }^{77}$ Certainly such stories were told in court and they indeed had this end. We may also see them as reports of the healers' own rationale, their attempts at the time to explain and cure illnesses. As noted above, their diagnoses and methods of healing were logical in the context of folk medicine, and there were no references to evil aims in these decisions and actions. The references to evil aims arose when people gossiped and speculated about why a healer could not cure her patient. Social knowledge was activated, and it also accumulated in these kinds of discussions. Moreover, as we have seen above, the healers took part in these discussions, which were also a crucial source of information for a healer who was searching for a socially and culturally acceptable source for an illness.

Our case also suggests that questions concerning the healer's morality were more complex than one might expect. In the first place, it seems that a healer's ability to use her or his power for both healing and harming lay at the core of the case. ${ }^{78}$ It made all healers potential witches. It also seems that, although some of them were already burdened with bad reputations, it did not prevent people from asking for their help. What is even more curious, the patients already suspected some of them from the outset and still they sought their help. The explanation for this might lie in the idea that a witch who had sent an illness could also heal it. Possibly, attempts to cure it as a natural illness had failed. Using a witch might represent the last possibility.

In any event, it seems that the healers' reputation worsened when they failed recurrently. They could not come up with the goods as healers. It destroyed trust in them and gave rise to suspicions about them. Consequently, a dissatisfied patient and her or his close relatives and friends looked for another, more reliable healer, who in the first phase was interested in their interpretations of the cause of the illness. The second healer might then say that s/he suspected the earlier one.

76 KA: VRO v. 1: 30.6., 5.7.1658.

77 STEWART \& STRATHERN (2004), p. 19.

78 Cfr. HonKo (1960), pp. 77, 108-109. 


\section{CONCLUSIONS}

The early modern understanding of illness was broader than ours. It did not regard illnesses as mere psycho-physical states with certain symptoms but it took also the patients' social context into account. Aetiological models also emphasised the importance of the origins of the illnesses and its connection with the patient's past actions. This meant that the diagnosis of an illness could change when, for one reason or another, the patient's behaviour was interpreted anew.

The position of the healer was further complicated because she possessed certain magical powers that she could use for both good and evil. People had to guess what the healer's intentions towards them were and what kind of inner essence or nature a healer had. Especially when a healer failed, suspicions about her or his ill will arose. On the other hand, there might already exist suspicions about a healer whose help was sought because early modern people believed that the best person to cure an illness was the one who had caused it.

People evaluated and moralised about each other's actions and behaviour by gossiping. From gossip they also put together pieces of information about one another. In this way they created a store of local knowledge, which I call "social knowledge». It included information about what a person had said or done in the past, and people tried to interpret her or his real nature by using that information. Healers also used it when they were diagnosing an illness, and they had to decide if it was personalistic or naturalistic in origin. First they listened to the patient's own suspicions. If a healer diagnosed that an illness was caused by a curse, $\mathrm{s} / \mathrm{he}$ then had to show who the witch was. This decision was based not only on the patient's suspicions but also on the social knowledge concerning a possible suspect. From this point of view, the process of healing was not so much medical as social.

A healer's work was based on trust. People had to believe that s/he was able to help them. When the trust was broken, the whole process of healing failed and led to a dead end. This kind of situation was possible when a healer or healers failed recurrently. Such cases also illuminated some other problems in the process of healing. The models of interpretation were very flexible and multifarious. They allowed new and uncertain diagnoses and interpretations to be made endlessly. The limits between illness and guilt, between the natural and the supernatural became blurred. As a result, the reality became chaotic and impossible to control.

Fecha de recepción: 31 de octubre de 2007.

Fecha de aceptación: 3 de noviembre de 2008. 